\title{
Student pharmacists' career choices: a survey of three Nigerian schools of pharmacy
}

\author{
Chukwuemeka M. UBAKA, Uche M. OCHIE, Maxwell O. ADIBE. \\ Received (first version): 27-Nov-2012 Accepted: 21-Jul-2013
}

\begin{abstract}
${ }^{*}$
Background: There is little data on the preferences of pharmacy students as regards their future pharmacy job choices in Africa and this has created concerns amongst licensing bodies, employers and also the institutions they graduate from.

Objectives: Career choices and factors that influence these choices of pre-registration pharmacists were assessed.

Methods: Final and fourth year students from three schools of pharmacy were approached with a previously validated and employed questionnaire comprising questions on future job choices and reasons for that job choice. Data collected were subjected to descriptive and inferential analysis. Results: Four hundred and eighty eight students took part in the study (response rate $71.5 \%$ ). Majority $(78.8 \%)$ was younger than 26 years and had a work experience (68.2\%). Job flexibility was significantly more important to females, while younger students considered salary most important $(p<0.05)$. Hospital and community practice were most preferred career choices. Other demographic factors (especially gender, marital status, previous degree and previous work experience) significantly affected career choices.

Conclusion: Age, gender, and previous work experience affect career choices of graduating pharmacy students. Patient-oriented practices (e.g. hospital and community) remain the most preferred careers.
\end{abstract}

Keywords: Students, Pharmacy; Education, Pharmacy; Career Choice; Nigeria

\author{
OPCIONES DE CARRERA DE LOS \\ ESTUDIANTES DE FARMACIA. ENCUESTA \\ EN TRES ESCUELAS DE FARMACIA \\ NIGERIANAS
}

\section{RESUMEN}

Antecedentes: Existen pocos datos sobre las preferencias de los estudiantes de farmacia sobre su futuro laboral en África y esto ha producido preocupación entre los organizamos acreditadores, patronos y las instituciones en las que se gradúan. Objetivos: Se evaluaron las elecciones de carrera y los factores que influencian esta selección entre los farmacéuticos pre-registro.

Métodos: Se abordó a estudiantes de último y cuarto año de las tres escuelas de farmacia con un cuestionario previamente validado y utilizado que contenía preguntas sobre elección de futuro laboral y motivos de esa elección. Los datos recogidos fueron sujetos a análisis descriptivo e inferencial. Resultados: Unos 488 estudiantes tomaron parte en el estudio (tasa de respuesta $71,5 \%$ ). La mayoría $(78,8 \%)$ era menor de 26 años y tenía experiencia laboral $(68,2 \%)$. La flexibilidad laboral era significativamente más importante para las mujeres, mientras que los estudiantes más jóvenes consideraba el salario como lo más importante $(\mathrm{p}<0,05)$. Las opciones de carrera profesional preferidas eran hospital y comunidad. Algunos otros factores demográficos (especialmente género, estado civil, titulaciones previas, y experiencia laboral previa) afectaban significativamente las opciones de carrera.

Conclusión: La edad, género, y experiencia laboral previa afectan las opciones de carrera de los estudiantes graduados en farmacia. Los ejercicios orientados al paciente (e.g. hospital y comunidad son las carreras preferidas.

Palabras clave: Estudiantes de Farmacia; Educación en Farmacia; Selección de Profesión; Nigeria

\section{INTRODUCTION}

There is a dearth of health professionals including pharmacists all over the world with majority of the developing countries suffering from health professional brain drain. ${ }^{1}$ As at 2012 , there were a little over 7300 registered pharmacists in Nigeria ${ }^{2}$, with its 2009 national population put at 160 million. With a ratio of 1 pharmacist to 22,000 people, this figure is worse than most developing countries. ${ }^{3}$ This has put a lot of pressure on the pharmacy education system to produce more (and hopefully Pharmacy Unit, Department of Clinical Pharmacy and Pharmacy Management, University of Nigeria, Nsukka

Uche Mabel OCHIE. PhD. Department of Clinical Pharmacy and Pharmacy Practice, University of Benin. Benin City (Nigeria).

Maxwell Ogochukwu ADIBE. PhD. Social Pharmacy Unit, Department of Clinical Pharmacy and Pharmacy Management, University of Nigeria. Nsukka (Nigeria). 
effective) pharmacists to meet up with the growing population of the sick and challenged. This is evident by the increase in number of newly partaccredited schools of pharmacy and the increase in number of pharmacy graduates yearly. With the profession's quest to meet up with various challenges such as the paradigm shift from a product based to a patient based profession, the millennium goals and the need for an all-inclusive (inter-disciplinary) approach to healthcare, it is expedient now more than ever, to produce competent pharmacists.

Pharmacy practice comprises different fields such as hospital practice, community practice, industry (production and marketing), academia and administrative pharmacy. With the former three accounting for majority of pharmacists practicing in Nigeria, newer areas such as journalism, public health pharmacists, consultancy etc, continue to play a background role, probably due to the poor remunerations in these settings. Graduate pharmacists are expected to build practice competencies as they undergo the mandatory oneyear pre-practice internship spanning any area of pharmacy practice before they are licensed to practice. Some employers of pharmacists (especially community pharmacists, industry and state and district health centers) continue to bemoan the shortage of pharmacists in these areas, with many vacant positions left unoccupied.

Some studies (though few) have assessed the factors that influence how pharmacy students make their future choices and locations. ${ }^{4,5}$ In a study by Savage and colleagues pharmacy students considered work environment and benefits before choosing a career and preferred to work in retail chain setting. ${ }^{6}$ In Malaysia, pharmacy students preferred hospital pharmacy and community pharmacy depending on the type of school. They also ranked salary, benefits and geographical location as most significant factors for selecting a career job. ${ }^{7}$ However, the conclusions drawn for most of these studies were restricted to their locations and thus a need to explore other settings.

The objectives of this study were to (1) assess the career choices which Nigerian pharmacy students make (2) assess the factors that influence the career choices of pharmacy students in Nigeria in three different schools of pharmacy.

\section{METHODS}

\section{Study design}

This was a cross sectional survey conducted in three schools of pharmacy in Southern Nigeria between the months of January and March 2011.

\section{Study location}

Three schools of pharmacy out of the four fully accredited in the Southern Region of Nigeria were conveniently sampled for this study. As at the time of this study, there were only nine "fully" council(board) accredited and government funded schools of pharmacy in Nigeria and five schools having partaccreditation or still seeking council board accreditation. The schools of pharmacy used in this study were those in University of Nigeria, Nsukka, University of Benin and Nnamdi Azikiwe University. The two former schools boast of the largest number of students and graduates each year in the country. Of note specifically, University of Nigeria graduates an average of 180 pharmacists (2005-2010 range; 160 to 198) annually. The latter school on the other hand recently (2010) received its accreditation and boasts of an entire student-strength of only 200 students for its 4 professional classes.

\section{Study instrument}

The questionnaire used for the study had earlier been developed and employed by Savage et al. ${ }^{6}$ It consisted of 19 questions separated into 3 sections. The first section assessed students' demographic variables such as age, gender, current study year, relationship status, prior work experience and educational background. The second section comprised a question, seeking to know student's response to the importance of some factors that influence their career goals. The measurement was done on a 5-point Likert scale (i.e. very low importance to very high importance). In the third section, students were asked to select the practice area they planned to practice upon after graduation, thereafter five years after graduation. The areas provided for selection were hospital, community practice (also known as retail/dispensing), industry, academics/research and "others", the latter being for areas outside the provided. Based on the areas chosen for practice after graduation, respondents were asked questions on factors of considerations for specifically chosen areas on a Likert scale as described above.

\section{Study participants}

Fourth (penultimate) and final (pre-graduation) year classes of the three schools of pharmacy were selected using a non-probabilistic convenience sampling. This selection was made on the basis (or assumption) that these set of students after parttime industrial trainings (i.e. the non-mandatory midsemester vacation jobs where students gain practice experience under licenced preceptors in a particular practice setting), interaction with recent graduates and length of time spent in pharmacy school would have a deeper knowledge of pharmacy practice areas.

\section{Study procedure}

An ethical approval was applied for through the Administrative/Research Review Office of each Faculty and approval obtained before the commencement of the study. In all the schools of pharmacy, students were approached just towards the end of a mandatory course/seminar. This was done to ensure late attendees were included in the study. An oral consent was received from the participating students after an earlier briefing. The study instrument was distributed at each site by at least two faculty members and students were required to self-fill the questionnaires. A maximum allotted time for the completion of the survey questionnaire in all of the centers was fifteen minutes. On completion of the questionnaires, 


\begin{tabular}{|c|c|c|c|c|c|c|c|}
\hline \multirow[t]{2}{*}{ Variable } & \multicolumn{2}{|c|}{$\begin{array}{l}\text { University of Nigeria } \\
(\mathrm{N}=280)\end{array}$} & \multicolumn{2}{|c|}{$\begin{array}{l}\text { University of Benin } \\
(\mathrm{N}=161)\end{array}$} & \multicolumn{2}{|c|}{$\begin{array}{l}\text { Nnamdi Azikiwe University } \\
(\mathrm{N}=47)\end{array}$} & \multirow{2}{*}{$\begin{array}{l}\text { TOTAL } \\
\text { No (\%) }\end{array}$} \\
\hline & No & $\%$ & No & $\%$ & No & $\%$ & \\
\hline \multicolumn{8}{|l|}{ Age, years } \\
\hline$<20$ & 1 & 0.4 & 3 & 1.9 & 1 & 2.1 & $5(1.0)$ \\
\hline $21-23$ & 95 & 33.9 & 66 & 41.0 & 32 & 68.1 & $193(39.5)$ \\
\hline $24-26$ & 110 & 39.3 & 65 & 40.4 & 12 & 25.5 & $187(38.3)$ \\
\hline $27-29$ & 59 & 21.1 & 20 & 12.4 & 1 & 2.1 & $80(16.4)$ \\
\hline$\geq 30$ & 15 & 5.4 & 7 & 4.3 & 1 & 2.1 & $23(4.7)$ \\
\hline TOTAL & 280 & 100 & 161 & 100 & 47 & 100 & 488 \\
\hline \multicolumn{8}{|l|}{ Gender } \\
\hline Female & 146 & 52.1 & 79 & 49.1 & 15 & 31.9 & $240(49.2)$ \\
\hline Male & 134 & 47.9 & 82 & 50.9 & 32 & 68.1 & $248(50.8)$ \\
\hline \multicolumn{8}{|l|}{ Current year of study } \\
\hline $4^{\text {th }}$ year & 135 & 48.2 & 79 & 50.8 & 34 & 72.3 & $248(50.8)$ \\
\hline $5^{\text {th }}$ year & 145 & 51.8 & 82 & 49.2 & 13 & 27.7 & $240(49.2)$ \\
\hline \multicolumn{8}{|l|}{ Relationship status } \\
\hline Single & 180 & 64.3 & 111 & 68.9 & 42 & 89.4 & $333(68.2)$ \\
\hline Involved in a relationship & 64 & 22.9 & 41 & 25.5 & 2 & 4.3 & $107(21.9)$ \\
\hline Engaged/Married & 36 & 12.9 & 9 & 5.6 & 3 & 6.4 & $48(9.8)$ \\
\hline \multicolumn{8}{|l|}{ Previous IT experience } \\
\hline Yes & 144 & 51.4 & 160 & 99.4 & 29 & 61.7 & $333(68.2)$ \\
\hline No & 136 & 48.6 & 1 & 0.6 & 18 & 38.3 & 155(31.8) \\
\hline \multicolumn{8}{|l|}{ IT areaI } \\
\hline Community Pharmacy & 81 & 56.2 & 116 & 72.5 & 21 & 72.4 & $218(65.5)$ \\
\hline Industry & 13 & 9.0 & 18 & 11.2 & 3 & 10.3 & $34(10.2)$ \\
\hline Hospital & 28 & 19.4 & 26 & 16.2 & 0 & 0 & $54(16.2)$ \\
\hline Others & 22 & 15.3 & 0 & 0 & 5 & 17.2 & $27(8.1)$ \\
\hline TOTAL & 144 & 100 & 160 & 100 & 29 & 100 & 333 \\
\hline
\end{tabular}

return of the forms was done with a ballot box. No honorarium was promised or given to any student.

\section{Outcome measures and data analysis}

The main outcomes measured included; Importance of various job factors in career goal selection, the career choices made by the students of the schools of pharmacy and reasons for selecting the specific career goals. Also changes in choice between immediately after graduation and five years after graduation was assessed. Other outcomes measured included differences in demographics in job consideration factors and choice of career. To achieve the aforementioned, data were extracted from the questionnaire, coded and entered into the SPSS version 16 for analysis. Simple descriptive statistics such as percentages and cross tabulation were used. A bar chart was also employed to show career choices by year of study and school of pharmacy. In order to calculate mean differences between demographic groups, Likert points were scored with corresponding values (e.g. very low importance scored one point and very high importance scored five points) and mean scores derived for each respondent and each questionnaire item. A chi square test and independent sample ttest were conducted to note if differences between proportions and mean scores between the two periods and demographic variables, respectively, were statistically significant. Analysis of variance was also used to note differences in choices within groups. A p-value of less than 0.05 was considered significant.

\section{RESULTS}

Four hundred and eighty eight students successfully completed the survey in the three schools of pharmacy representing an overall participation rate of $71.5 \%$ (488/682). Individual school response rates were follows; University of Nigeria 280/374 (74.9\%), Nnamdi Azikiwe University 47/58 (81.0\%) and University of Benin 161/250 (64.4\%). Non responders were majorly absentees from classes.

\section{Demography of participating students}

There were nearly equal male and female students in this study with majority of them being within the

\begin{tabular}{|l|c|c|c|c|c|c|c|}
\hline Table 2: Importance of General Job Considerations on Student's Career Choices in Three Schools of Pharmacy \\
\hline $\begin{array}{c}\text { General Job } \\
\text { Considerations, n=488 }\end{array}$ & $\begin{array}{c}\text { Very Low } \\
\text { Importance }\end{array}$ & $\begin{array}{c}\text { Low } \\
\text { Importance }\end{array}$ & Neutral & $\begin{array}{c}\text { High } \\
\text { Importance }\end{array}$ & $\begin{array}{c}\text { Very High } \\
\text { Importance }\end{array}$ & $\begin{array}{c}\text { Percentage } \\
\text { PR }\end{array}$ & $\begin{array}{c}\text { Mean } \\
\text { Response }\end{array}$ \\
\cline { 2 - 9 } & No. (\%) & No. (\%) & No. (\%) & No. (\%) & No. (\%) & \% \\
\hline $\begin{array}{l}\text { Benefits (e.g. leave, } \\
\text { allowances) }\end{array}$ & $16(3.3)$ & $38(7.8)$ & $80(16.4)$ & $189(38.7)$ & $165(33.8)$ & 72.5 & 3.92 \\
\hline Salary & $3(0.6)$ & $10(2.0)$ & $36(7.4)$ & $141(28.9)$ & $297(60.9)$ & 89.7 & 4.47 \\
\hline Geographic location & $6(1.2)$ & $20(4.1)$ & $107(21.9)$ & $194(39.8)$ & $159(32.6)$ & 72.3 & 3.99 \\
\hline Work environment & $4(0.8)$ & $12(2.5)$ & $49(10.0)$ & $207(42.4)$ & $214(43.9)$ & 86.3 & 4.26 \\
\hline Advancement opportunities & $1(0.2)$ & $4(0.8)$ & $22(4.5)$ & $135(27.7)$ & $324(66.4)$ & 94.0 & 4.59 \\
\hline Flexible work schedule & $18(3.7)$ & $31(6.4)$ & $118(24.2)$ & $195(40.0)$ & $126(25.8)$ & 65.8 & 3.78 \\
\hline PR= Positive response
\end{tabular}


Ubaka CM, Ochie UM, Adibe MO. Student pharmacists' career choices: a survey of three Nigerian schools of pharmacy. Pharmacy Practice 2013 Jul-Sep;11(3):149-155

\begin{tabular}{|c|c|c|c|c|c|c|c|}
\hline \multirow[b]{2}{*}{ Career choice } & \multicolumn{2}{|c|}{ University of Nigeria } & \multicolumn{2}{|c|}{ Nnamdi Azikiwe University } & \multicolumn{2}{|c|}{ University of Benin } & \multirow{2}{*}{$\begin{array}{c}\text { Total } \\
\mathrm{N}(\%)\end{array}$} \\
\hline & $\begin{array}{c}4^{\text {th }} \text { Year, } \\
\mathrm{N}(\%)\end{array}$ & $\begin{array}{c}5^{\text {th }} \text { Year } \\
\mathrm{N}(\%)\end{array}$ & $\begin{array}{c}4^{\text {th }} \text { Year, } \\
N(\%)\end{array}$ & $\begin{array}{c}5^{\text {th }} \text { Year } \\
N(\%)\end{array}$ & $\begin{array}{c}4^{\text {th }} \text { Year, } \\
N(\%)\end{array}$ & $\begin{array}{c}5^{\text {th }} \text { Year } \\
\mathrm{N}(\%)\end{array}$ & \\
\hline Hospital & $28(20.7)$ & $55(37.9)$ & $8(23.5)$ & $2(15.4)$ & $23(29.1)$ & $25(30.9)$ & $141(28.9)$ \\
\hline Community Pharmacy & $42(31.1)$ & $42(29.0)$ & $4(11.8)$ & $2(15.4)$ & $14(17.7)$ & $27(33.3)$ & $131(26.9)$ \\
\hline Industry & $40(29.6)$ & $23(15.9)$ & $13(38.2)$ & $4(30.8)$ & $19(24.1)$ & $13(16.0)$ & $112(22.9)$ \\
\hline Academics/ Research & $19(14.1)$ & $20(13.8)$ & $5(14.7)$ & $5(38.5)$ & $20(25.3)$ & $11(13.6)$ & $80(16.4)$ \\
\hline Outside Pharmacy & $6(4.4)$ & $5(3.4)$ & $4(11.8)$ & $0(0)$ & $3(3.8)$ & $5(6.2)$ & $23(4.7)$ \\
\hline Total & $135(100)$ & $145(100)$ & $34(100)$ & $13(100)$ & $79(100)$ & $81(100)^{4}$ & $487(100)$ \\
\hline
\end{tabular}

ages of $21-26$ years, accounting for over $77 \%$ of all participating students. Majority of the students were singles $(68.2 \%, p<0.01)$ and had no prior college or university degree $(95.7 \%, p<0.01)$. Lastly, a good number of the students $(68.2 \%, \mathrm{p}<0.01)$ had gone for a vacation training with most $(65.5 \%, p<0.01)$ getting placements in community pharmacies. The complete demographic results are presented in Table 1.

\section{Influential Factors for General Career Consideration}

When asked what factors they considered important in making job choices (Table 2), majority of the students favorably chose advancement opportunities (94.0\% positive response, mean score of 4.59 of 5.00$)$ and salary $(89.7 \%$ positive responses, mean score of 4.47 ) as the two most important factors. The least preferred factor was flexible work schedule with only $65.8 \%$ positive response and 3.78 mean score.

When controlling for demographic variables, more female students thought flexibility was a better factor than male students ( 3.88 vs. $3.68, p=0.026$ ). Also female students felt geographical location was of more importance to them than their male counterparts ( 4.07 vs. $3.91, p=0.058)$, though not statistically significant. Students who were less than 24 years opted for salary as a key factor much more than older students ( 4.58 vs. $4.41, p=0.016)$. Single students said advancement opportunities was of more priority to them compared to students involved in a relationship (4.63 vs. $4.49, p=0.04)$. For students with a previous university/college degree, advancement in opportunities played more role in job choice than students without any prior degree (4.82 vs. $4.59, p=0.017$ ). Students with no vacation work experience were less disposed to the choices of flexible work schedule (3.89 vs. $3.53, p<0.001)$ and geographical location ( 4.05 vs. $3.85, p=0.023$ ) compared to more work experienced students.

\section{Career choices}

Students' future career choices after graduation are presented in Table 3. Of particular note are the choices of hospital practice $(28.9 \%)$ and community pharmacy practice $(26.9 \%)$ as most preferred. Academics and research attracted $16.4 \%$ of the student's choices and careers outside pharmacy attracted only $4.7 \%$ of the students' choices. Differences in these career paths by pharmacy school are also displayed in Figure 1. Significantly more students of Nnamdi Azikiwe University chose practice in the industry more than other practice settings (NAU $=36.5 \%, \quad U N N=22.5 \%, \quad U B=20.0 \%$; $\mathrm{p}<0.05)$. Other career choices made by the students suggested that more students from University of Nigeria Nsukka preferentially chose community pharmacy practice $(\mathrm{UNN}=30.0 \%, \mathrm{NAU}=12.8 \%$, UB $=25.6 \% ; p>0.05)$.

From a more analytical point, female students' choices were more predisposed towards hospital practice $(38.2 \%$ vs. $19.8 \% ; p<0.01)$ and males towards pharmacy practice in industry $(31.2 \%$ vs. $14.6 \% ; p<0.001)$. Final year students $(34.3 \%$ vs. $23.8 \%$; $p<0.05)$ preferred careers in hospitals more than penultimate year students who preferred jobs within the industry $(29.0 \%$ vs. $16.7 \%$; $p<0.05)$. Interestingly also, more than one third $(34.0 \%)$ students who were either married or involved in a serious relationship said they would like to work in a hospital. This figure was significantly $(p=0.04)$ higher than choices of single students $(26.5 \%)$. Students with a prior college degree said they preferred academics and research $(33.3 \%$ vs. $15.5 \%$; $p<0.01)$, while those without preferred hospital practice $(29.5 \%$ vs. $13.6 \%, p<0.05)$ Nearly half of the students who had an earlier work experience in the hospital $(44.4 \%)$ and community pharmacies $(41.2 \%)$ said they would like to continue in those respective fields. Career choice five years after graduation did not differ significantly from choices immediately after graduation in any of the fields. Notable changes however, were increases in preferences for academia/research $(16.4 \%$ to $19.2 \%)$ and areas outside pharmacy $(4.7 \%$ to $5.9 \%)$.

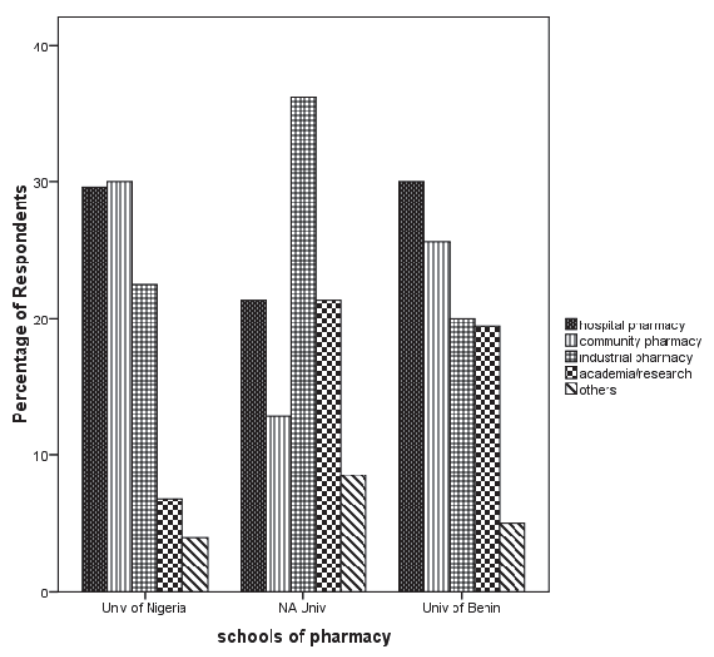

Figure 1. Distribution of pharmacy students' (by pharmacy school) career goals immediately after graduation 


\begin{tabular}{|c|c|c|c|c|c|c|}
\hline Career Choice & VLI & $\mathrm{LI}$ & $\mathrm{N}$ & $\mathrm{HI}$ & $\mathrm{VHI}$ & $\% \mathrm{PR}$ \\
\hline \multicolumn{7}{|l|}{ Hospital } \\
\hline Daily interaction with other health workers & $2(1.4)$ & $6(4.3)$ & $13(9.2)$ & $52(36.9)$ & $68(48.2)$ & 85.1 \\
\hline $24 \mathrm{hr}$ call & $24(17.0)$ & $31(22.0)$ & $50(35.5)$ & $21(14.9)$ & $15(10.6)$ & 25.5 \\
\hline Service to hospitalized patients & $1(0.7)$ & $1(0.7)$ & $11(7.8)$ & $54(38.3)$ & $74(52.5)$ & 90.8 \\
\hline Compounding extemporaneous drugs & $4(2.9)$ & $10(7.1)$ & $38(27.1)$ & $41(29.3)$ & $47(33.6)$ & 62.4 \\
\hline \multicolumn{7}{|l|}{ Community Pharmacy practice } \\
\hline Daily interaction with general public & 0 & $1(0.8)$ & $7(5.3)$ & $50(38.2)$ & $73(55.7)$ & 93.9 \\
\hline Fast pace environment & $3(2.3)$ & $4(3.1)$ & $33(25.4)$ & $61(46.9)$ & $29(22.3)$ & 68.7 \\
\hline High financial reward & $1(0.8)$ & $6(4.6)$ & $17(13.0)$ & $47(35.9)$ & $60(45.8)$ & 81.7 \\
\hline Counseling opportunities & 0 & 0 & $10(7.7)$ & $36(27.7)$ & $84(64.6)$ & 92.3 \\
\hline \multicolumn{7}{|l|}{ Industry } \\
\hline Daily quality assurance of equipment & 0 & $1(0.9)$ & $11(9.8)$ & $45(40.2)$ & $55(49.1)$ & 92.6 \\
\hline High financial reward & 0 & $2(1.8)$ & $6(5.5)$ & $31(28.2)$ & $71(64.5)$ & 92.7 \\
\hline Establishment of status within the healthcare & 0 & $2(1.8)$ & $7(6.2)$ & $43(38.4)$ & $60(53.6)$ & 91.9 \\
\hline \multicolumn{7}{|l|}{ Academics/Research } \\
\hline Be your own boss & $5(6.2)$ & $3(3.8)$ & $25(31.2)$ & $25(31.2)$ & $22(27.5)$ & 58.7 \\
\hline Flexible scheduling & $1(1.2)$ & $3(3.8)$ & $13(16.2)$ & $33(41.2)$ & $30(37.5)$ & 78.7 \\
\hline Academic opportunities & 0 & 0 & $7(8.9)$ & $12(15.2)$ & $60(75.9)$ & 91.1 \\
\hline
\end{tabular}

\section{Factors important in specific career choice}

Students, who chose hospital pharmacy as their future career destination, said they considered service delivery to hospitalized patients $(90.8 \%)$ and daily interaction with other health personnel most important $(85.1 \%)$. The 24 hour call system was the least preferred option by these students, with only a quarter of them selecting it. For students preferring community pharmacy practice, a fast paced environment, was the least $(68.7 \%)$ option for making that choice. Daily interactions with the public (93.9\%) and counseling opportunities (92.3\%) were considered most paramount. Students regarded all the reasons highly in their selection of practice in the industry with all the reasons attracting over $90 \%$ positive responses. Other important factors are also displayed on Table 4

\section{DISCUSSION}

There has been an increase in recent years in the number of newly registered pharmacists in Nigeria, generally due to the increase in the number of newly accredited pharmacy schools and increased number of applicants and graduates. This increase has not addressed the severe shortfall of pharmacists in the country and it has caused a disproportionate distribution of these professionals in practice areas such as research, administrative pharmacy and pharmacy journalism which continue to witness low employment patronage. It was therefore expedient to identify career areas graduate pharmacists are preferring and reasons for their preferences.

In our study, there were more male respondents than females (though females outnumber males in classes), an observation very much dissimilar to other studies on career choices. ${ }^{7,8}$ Also majority of them (over two third) were single. Pharmacy as a choice of study continues to attract younger people with over three-quarters of the pre-graduating students at ages less than 26 years. This has also been shown in some other studies assessing career paths of students. ${ }^{6,9}$ Also an impressive number, two thirds of pharmacy students had a prior work experience in a pharmacy setting, though with majority of such students coming from University of Benin. Some schools of pharmacy are making vacation pharmacy jobs for students mandatory, with some other schools attaching some financial benefits to it to encourage students.

This study explored pre-graduates' job choices and the considerations they give for these job choices they made. Advancement in opportunities, salary and work environment were the major factors being considered before a job choice is made. This is similar to results obtained by Besier and Yang $^{10}$ in their study which pointed job satisfaction, salary and advancement opportunities as most important job choice influencing factors and by Hasan and colleagues $^{7}$, which showed salary was the greatest influencing factor among Malaysian students. Majority of the students who study pharmacy come from poor to average background or are expected to "come home with lots of money" after graduation and these students are often pressured by the need to be "financially successful". However, advancement opportunities such as career development and owning a company were most highly considered. This however goes to show that while income may be important; these students do seriously consider their future. Generally, students in our study did not highly consider benefits (such as leaves and allowances) and geographical location, important factors for job choices in contrast to studies performed in two schools of pharmacy in the United States. ${ }^{6,11}$ Popular belief among pharmacy professionals and members of faculty is that salary was and is the major stimulant for graduates' job choices. This was evident among younger students, whose passion for practice is mostly driven by financial benefits. With most annual internship incomes (especially in hospital postings) over 1.8 million naira (approx. 12,000 USD), most students look forward to receiving such earnings, and bearing in mind that incomes after licensure (in practice areas such as community, industry and academics where call allowances are not paid) might be smaller. 
The choice of hospital and community pharmacy practice by majority of the students does not come as a surprise, as has been exhibited in some other studies. ${ }^{6,12}$ Currently in Nigeria, both practice areas offer the highest number of job placements for pharmacists with only practice in the industry coming any close. With over 80 federally funded hospitals, 500 state-owned hospitals and 2000 registered community premises, most pharmacists are disposed to making choices in these areas on the basis of availability and financial remuneration. Previous work experience in hospital and community practice was positively associated with the retained choice of both areas, which may suggest the predictive effect of previous work experience and future job choice. Females were more predisposed to the choice of hospital practice than males citing reasons such as service provision and daily interaction with other health workers; key components of pharmaceutical care, as very paramount in their choice. Some studies on Nigerian students have shown female students having better attitude to the practice of pharmaceutical care than male students. ${ }^{13,14}$

Final year student career choices tended significantly towards practice settings with more patient contact. In most pharmacy schools in Nigeria, student exposure to hospital and community pharmacy practice commences in the final study year during the clinical clerkship course. The concept of pharmaceutical care is practically introduced at this stage and students are encouraged to directly participate in drug therapy evaluation and patient education. This may have skewed the choices of final year students significantly towards hospital and community practice. A significantly greater percentage of pharmacy students of Nnamdi Azikiwe University in Anambra State, chose pharmacy practice in the industry and this may have been hugely influenced by the "highly industrialized" environment the school is located in. Anambra State is the commercial and industrial hub of the south-east and houses the largest number of pharmaceutical industries and importation companies and this could have influenced the choices of these students. An impressive $16 \%$ of students wanted to practice as academicians or researchers. Impressive because, this figure was much higher than those obtained in a study in Malaysia, which reported an interest of between $2-5.6 \%$ for private and public university students. ${ }^{7}$ Brooks in his study underscores the need for student pharmacists to embrace the opportunity of taking an academic position which can offer a mix of variety, autonomy and importantly flexibility. ${ }^{15}$ Another study reported low patient contact in academic practice as a major reason students did not intend to pursue an academia, and suggested that increased patient contact and teaching responsibilities were important and could encourage students towards an academic career. ${ }^{16}$
Most interestingly also, some students said they would choose areas outside pharmacy practice, majority citing "the need to make more money" or "it's a personal reason" as their reasons. Though the number citing this is small compared to the study of Hassan et al. ${ }^{7}$, the reasons were the same. Common career areas outside pharmacy practice which attract Nigerian pharmacists include telecommunications, financial consultancy and politics. The prevalence of pharmacists in these areas forms the focus of future research. Also future studies that would explore reasons and prevalence of pharmacists exit to developed countries (braindrain) would be hugely important in order to address the shortages of health professionals, developing countries currently experience.

This study suffered some limitations. Firstly, results of this study, though obtained from the three schools of pharmacy from the Southern region, may not represent job choices of students in other schools of pharmacy in other regions of the country. Secondly, the questionnaire did not adequately define "other careers outside pharmacy practice" and some students, though little, assumed it to be new areas of pharmacy. This may have altered the validity of responses derived from that question.

\section{CONCLUSIONS}

This study showed that majority of the students preferred hospital and community practice with advancement opportunities and salary topping the factors they considered in making their choices. There were also significant differences in choices made on the basis of gender, prior school degree and previous work experience. Educators are encouraged to add to curriculum, discussions on emerging career paths that are suffering serious shortages especially in developing countries.

\section{ACKNOWLEDGEMENTS}

The authors wish to express their gratitude to the Management of Vinco Pharma Nigeria for their financial support through its Pharmacy Education Fund. In addition also, the authors acknowledge the efforts of Pharmacist Mba Kenneth, for his assistance during the data collection phase.

\section{CONFLICT OF INTEREST}

The authors declare that there is no conflict of interest

Funding: An undergraduate student support was received from Vinco Pharma Educational Fund for assistance in travels/accommodation during data collection in the two schools of pharmacy.

\section{References}

1. Hawthorne N, Anderson C. The global pharmacy workforce: a systemic review of the literature. Human Resources for Health. 2009;7:48 doi:10.1186/1478-4491-7-48 
2. Pharmacists Council of Nigeria. List of Licensed Pharmacists as at November, 2012 Available at: http://www.pcn.gov.ng/WEB licenced pharmacists.pdf (Accessed 27-November-2012).

3. Kheir N, Zaidan M, Younes H, El Hajj M, Wilbur K, Jewesson PJ. Pharmacy Education and Practice in 13 Middle Eastern Countries. Am J Pharm Educ. 2008;72(6):133.

4. Carvajal MJ, Hardigan P. First-job preferences and expectations of pharmacy students: intergender and interethnic comparisons. J Am Pharm Assoc (Wash). 1999;39(1):32-40.

5. Pearson ML, Andres L. Job location decisions of pharmacy graduates in British Columbia. Am J Pharm Educ. 2010;74(4):74.

6. Savage LM, Beall JW, Woolley TW. Factors that influence the career goals of pharmacy students. Am J Pharm Educ. 2009;73(2):28.

7. Hasan SS, Kwai Chong DW, Ahmadi K, Se WP, Hassali MA, Hata EM, Hadi MA, Sridhar SB, Ahmed SI, Yean LB, Efendie B. Influences on Malaysian Pharmacy Students' Career Preferences. Am J Pharm Educ. 2010;74(9):166.

8. Siracuse MV, Schondelmeyer SW, Hadsall RS, Schommer JC. Third-year pharmacy students' work experience and attitudes and perceptions of the pharmacy profession. Am J Pharm Educ. 2008;72(3):50.

9. Siracuse MV, Schondelmeyer SW, Hadsall RS, Schommer JC. Assessing career aspirations of pharmacy students. Am J Pharm Educ. 2004;68(3):75.

10. Besier JL, Jang R.Factors affecting practice-area choices by pharmacy students in the Midwest. Am J Hosp Pharm. 1992;49(3):598-602.

11. Traynor AP, Sorensen TD. Student pharmacist perspectives of rural pharmacy practice. J Am Pharm Assoc (2003). 2005;45(6):694-699.

12. Machado C, Zapantis A, Singh-Franco D, Marsh WA, Beckey C. Effect of faculty-mediated interventions on pharmacy students' pursuit of postgraduate training. Am J Health Syst Pharm. 2008;65(2):158-163. doi:10.2146/ajhp070249.

13. Udeogaranya PO, Ukwe CV, Ekwunife OI. Assessment of attitudes of University of Nigeria pharmacy students toward pharmaceutical care. Pharm Pract (Granada). 2009;7(3):145-149. doi:10.4321/S1886-36552009000300003

14. Oparah AC, Udezi WA, Odili VU. Nigerian pharmacy students' attitude toward pharmaceutical care. International Journal of Pharmacy Education. 2006;1:1-8.

15. Brooks AD. Considering academic pharmacy as a career: opportunities and resources for students, residents and fellows. Currents in Pharmacy Teaching and Learning 2009;1(1):2-9. doi:10.1016/j.cptl.2009.05.001,

16. Eiland LS, Flowers SK, Andurkar S, O’Brocta R, Prabhu S, Medon PJ. A comparative study of student and faculty perspectives regarding career opportunities in pharmacy academia. Currents in Pharmacy Teaching and Learning 2010;2(1):39-51. doi:10.1016/j.cptl.2009.12.005 